\title{
PERBANDINGAN TEKNIK PEMERAHAN ASI TANGAN DENGAN MANUAL BREAST PUMP TERHADAP KENYAMANAN IBU DAN KUALITAS ASI
}

\author{
Siti Sopiatun ${ }^{1}$, Heda Melinda N Natapawira ${ }^{2}$, Meita Dhamayanti ${ }^{3}$, \\ ${ }^{1}$ Program Kebidanan Fakultas Kedokteran Universitas Padjadjaran \\ ${ }^{2,3}$ Departemen Ilmu Kesehatan Anak Fakultas Kedokteran Universitas Padjadjaran \\ 1'karsi.nasya@gmail.com, ${ }^{2}$ heda_1155@yahoo.com ${ }^{3}$ meita.dhamayanti@unpad.ac.id
}

Kata Kunci :

ASI,Teknik pemerahan tangan, Manual breast pump, Kenyamanan, Kualitas ASI
Keywords:

breast milk, hand

expressed techniques, manual breast pump, comfort, quality of

breast milk

\section{Info Artikel}

Tanggal dikirim : 8 Juni 2020 Tanggal direvisi : 23 Juli 2020 Tanggal Diterima: 24 Juli 2020 DOI: 10.36341 /jomis.v4i2.1322 Creative Commons AttributionNonCommercial-ShareAlike 4.0 International License.

\begin{abstract}
ABSTRAK
Cakupan ASI eksklusif yang rendah disebabkan oleh salah satu faktor yaitu ibu bekerja. Pemerintah mendukung program ASI eksklusif terhadap ibu bekerja dengan mempromosikan pemberian ASI dengan cara diperah. Pemerahan ASI dapat dilakukan menggunakan tangan dan alat seperti manual breast pump.Teknik pemerahan ASI dapat dipengaruhi oleh pengalaman ibu dan rasa nyeri pada saat pemerahan, hal tersebut dapat menimbulkan rasa nyaman ketika ibu melakukan pemerahan. Perbedaan teknik pemerahan menyebabkan kontaminasi bakteri dan jamur yang berbeda. Tujuan penelitian ini yaitu untuk menganalisis perbedaan teknik pemerahan ASI tangan dan manual breast pump terhadap kenyamanan ibu dankualitas ASI.Penelitian ini menggunakan desain observasional dengan pendekatan cross-sectional. Sampel penelitian adalah 35 orang ibu menyusui yang sudah memenuhi syarat kriteria inklusi dan eksklusi. Melakukan pengukuran kenyamanan ibu dan kualitas ASI dengan analisis data menggunakan uji Mann Whitney, Wilcoxon, dan McNemar. Hasil penelitian didapatkan skor kenyamanan pada teknik pemerahan ASI tangan mempunyai rata-rata 65,6 dan manual breast pump 59,5. Terdapat perbedaan yang signifikan pada teknik pemerahan terhadap kenyamanan ibu $(\mathrm{p}=0,046)$. Teknik pemerahan tangan terkontaminasi jamur 60\%, total bakteri Mesofil aerob $20 \%$, dan enterobakter $17,1 \%$. Teknik pemerahan manual breast pump terkontaminasi jamur $80 \%$, total bakteri Mesofil aerob 8,6\%, dan enterobakter 20\%. Kualitas ASI pemerahan tangan lebih baik dibandingkan manual breast pump $(\mathrm{p}=0,032)$. Disimpulkan bahwa teknik pemerahan tangan lebih nyaman dan mempunyai kualitas ASI lebih baik dibandingkan teknik pemerahan manual breast pump.
\end{abstract}

\begin{abstract}
The scope of exclusive breastfeeding is low caused by many factors, one of which is a working mother. The government supports the program of exclusive breastfeeding for mothers by promoting breastfeeding by expressed breast milk. Expressed breast milk can be done by hand and manual tools such as pump. Expressed breast milk can be influenced by mother's experience and the pain at the time of expressing breast milk, this can lead to a sense of comfort. The differences in expressing techniques might lead to contamination of different bacteria and fungi. the purpose of this research is to analyze the differences in hand milking techniques and manual breast pump on the comfort of the mother and the quality of breast milk This was an observational study with cross sectional approach and conductive in Taman Sari district, Bandung. The samples were 35 mothers who fulfilled the inclusion and exclusion criteria. Mann Whitney, Wilcoxon and McNemar were used in examining mothers' comfort and breast milk quality. The result of of comfort score showed 65.6 in hand expressed and 59.5 has in manual breast pump. There were several significant differences in expressing techniques to mothers'comfort $(p=0.046)$. Hand expressing were contaminated by yeast (60\%), total mesophilic bacteria (20\%), and enterobacter (17.1\%). Manual breast pump was contaminated by yeast (80\%), total mesophilic bacteria (8.6\%), and enterobacter (20\%). Breast milk quality in hand expressed was better than the manual breast pump ( $p=$ 0.032). It was concluded that hand expressed more comfortable and had better quality breast milk than manual breast pump techniques.
\end{abstract}




\section{PENDAHULUAN}

Pemberian ASI (Air Susu Ibu) eksklusif merupakan proses memberikan makan pada bayi hanya ASI saja, baik secara langsung dari payudara atau yang diperah dahulu (ASI perah), tanpa penambahan cairan atau makanan padat terkecuali vitamin, suplemen, dan obatobatan dengan alasan bayi sakit. ${ }^{1}$ Pemberian ASI eksklusif selama 6 bulan pertama kehidupan dan terus menyusui hingga 2 tahun sudah direkomendasikan oleh World Health Organization (WHO). Promosi ASI eksklusif adalah intervensi yang paling efektif untuk mengurangi angka kematian bayi, terutama di negara berkembang. ${ }^{1}$

Berdasarkan Profil Kesehatan Indonesia tahun 2013 cakupan jumlah pemberian ASI eksklusif di Indonesia sebesar 54,3\% sedikit lebih meningkat dibandingkan dengan tahun 2012 sebesar $48,6 \%$, sedangkan jumlah cakupan ASI eksklusif di Jawa Barat sebesar 33,65\% meningkat dibandingkan tahun 2012 sebesar 31,2\% dan merupakan provinsi peringkat kedua yang cakupannya rendah. ${ }^{2}$ Cakupan ASI eksklusif di Kab Bandung tahun 2012 sebesar $14,7 \%{ }^{3}$

Peraturan Pemerintah no 33 tahun 2012 pasal 6 dan 7 menyatakan setiap ibu yang melahirkan harus memberikan ASI eksklusif kepada bayi yang dilahirkannya, kecuali ada indikasi medis, ibu tidak ada, ibu terpisah dari bayi. ${ }^{2}$ Masalah yang timbul dalam memberikan ASI eksklusif tidak hanya kurangnya edukasi pada saat kunjungan antenatal care $^{2}$ tetapi pengetahuan ibu tentang proses pemerahan merupakan penyebab utama yang mengakibatkan ibu tidak memberikan ASI eksklusif, pada saat ibu kembali bekerja. ${ }^{4}$ waktu yang dibutuhkan ibu selama bekerja sekitar 7-10 Jam, hal tersebut sangat mempengaruhi pemberian ASI eksklusif. $^{5}$

Berdasarkan data dari Riset Kesehatan Dasar tahun 2013 yang diambil dari pekan
ASI seduania, persentase anak umur 0-23 bulan yang masih disusui menurut karakteristik pekerjaan ibu di Indonesia yaitu ibu tidak bekerja sebesar 76,7\%, pegawai $72,1 \%$, wiraswasta $80,3 \%$, petani/nelayan/buruh $82,9 \%$, dan lainnya $72,0 \% .{ }^{6}$ Langkah mendukung peningkatan pemberian ASI eksklusif pada ibu bekerja sudah tercermin dalam pekan ASI sedunia.Isi dari program tersebut menjelaskan bahwa pentingnya untuk meningkatkan kesadaran dan kepedulian memberikan ASI eksklusif pada ibu bekerja. $^{6}$ Pemerintah mendukung program ASI eksklusif terhadap ibu bekerja dengan mempromosikan pemberian ASI dengan cara diperah. ${ }^{2}$ ASI perah merupakan ASI yang diperah dari payudara ketika ibu terpisah dari bayinya atau ibu bekerja kembali, kaum ibu yang bekerja tetapi masih ingin menyusui bayinya sangat dianjurkan untuk pemerahan ASI dan menyimpannya. ${ }^{6}$ ASI perah merupakan solusi yang baik membantu ibu bekerja untuk terus memberikan ASI eksklusif. Alasan ibu tidak memberikan ASI karena ibu tidak mengerti bagaimana teknik pemerahan ASI, ibu beralasan pemerahan ASI harus menggunakan pompa, sedangkan jika pemerahan langsung menggunakan tangan ibu beralasan sangat merepotkan dan hasil ASI yang diperah sedikit. ${ }^{4}$ Hasil penelitian tersebut sejalan dengan penelitian di Klantan Malaysia tahun 2012 yaitu ASI perah sangat dianjurkan karena dalam penelitian ini telah mengeksplorasi persepsi dan pengalaman yang berkaitan dengan kelayakan, penerimaandan keamanan ASI perah di kalangan ibu bekerja. $^{4}$

Kunci keberhasilan pemberian ASI eksklusif bagi ibu bekerja terletak pada metode pemerahan, penyimpanan dan pemberian ASI yang sudah diperah, hal tersebut memerlukan dorongan dan dukungan dari keluarga dan orang sekitarnya termasuk tempat bekerja. 
Praktek pemberian ASI eksklusif perlu ditingkatkan bagi bayidan ibu untuk mencapai manfaat maksimal misalnya, menurunkan kejadian infeksi dan angka kematian bayi. ${ }^{4}$

Keberhasilan ASI eksklusif dapat dikaitkan dengan teknik pemerahan. Sebuah penelitian menjelaskan hubungan teknik pemerahan dengan pengalaman ibu dalam pemerahan ASI. Penelitian tersebut menjelaskan teknik pemerahan berhubungan dengan pengalaman ibu melakukan pemerahan yang dilihat dari beberapa aspek, dan sensitivitas nyeri pada saat pemerahan. ${ }^{8,9}$ Faktor tersebut berhubungan dengan keberhasilan pemerahan dan tingkat kenyamanan ibu. Kenyamanan ibu pada saat melakukan pemerahan merupakan tolak ukur untuk melanjutkan pemberian ASI eksklusif, yang didukung oleh beberapa faktor baik lingkungan sosial, atau keluarga. ${ }^{10}$

Teknik pemerahan ASI dapat menggunakan tangan langsung atau alat seperti breast pump. Salah satu risiko dari teknik pemerahan yaitu akan memengaruhi terhadap kualitas ASI dari segi jumlah bakteri Mesofil aerob, bakteri patogen, enterobakter, dan Jamur. $^{10}$ Dampak tersebut dipengaruhi oleh teknik dalam pemerahan ASI baik dari segi kebersihan tangan, sanitasi lingkungan, alat pompa, dan tempat penyimpanan. ${ }^{11}$

Hasil penelitian menjelaskan bahwa pemerahan ASI di rumah dan di fasilitas kesehatan bisa dilakukan dengan cara menggunakan tangan langsung atau breast pump, tetapi harus memperhatikan kesterilan alat pompa, dan personal hygiene, sehingga mempunyai perbandingan signifikan terhadap kontaminasi bakteri yang dilihat dari jumlah bakteri Mesofil aerob, enterobakter, bakteri patogen yaitu sekitar $59,6 \%$ dan $39,6 \%{ }^{11}$ indikator untuk mengukur kualitas ASI yaitu dengan cara menghitung jumlah bakteri Mesofil aerob, enterobakter, bakteri patogen. Semakin tinggi jumlah indiator yang ada pada ASI perah semakin buruk nilai/kualitas ASI tersebut. $^{11}$

\section{Tujuan}

1) Untuk menganalisis perbedaan teknik pemerahan ASI tangan dan manual breast pump terhadap kenyamanan ibu

2) Untuk menganalisis perbedaan teknik pemerahan ASI tangan dan manual breast pump terhadap kualitas ASI

\section{TINJAUAN PUSTAKA}

ASI adalah cairan hidup yang mengandung sel-sel darah putih, immunoglobulin, enzim dan hormon, serta protein spesifik dan zat-zat gizi lainnya yang diperlukan untuk pertumbuhan dan perkembangan janin ${ }^{12}$ Usia bayi , pekerjaan ibu dan pengetahuan sangat memengaruhi seorang ibu dalam memberikan ASI. ${ }^{13}, 14,15$ Pemberian ASI juga diutamakan bagi ibu yang bekerja dengan memberika ASI perah Pemerahan ASI adalah upaya mengeluarkan ASI dari payudara ibu secara manual atau dengan menggunakan alat khusus. ${ }^{16}$ ASI perah tidak akan basi sampai waktu tertentu jika proses penyimpanannya benar, misalnya ASI jika disimpan pada suhu ruangan (1629 0C) akan bertahan sampai 3-4 jam, tetapi jika cara pemerahannya dalam kondisi yang sangat bersih ASI akan bertahan sampai 6-8 jam. Jika disimpan pada lemari pendingin dengan suhu $\leq 4$ 0C ASI akan bertahan sampai 72 jam, tetapi jika cara pemerahannya dalam kondisi sangat bersih maka akan bertahan sampai 5-8 hari. $^{17}$ Teknik pemerahan berhubungan berkaitan erat dengan meningkatnya pengeluaran prolaktin yang menyebabkan banyaknya volume ASI, kejadian tersebut disebabkan alat pemerahan dapat merangsang payudara dan jaringan puting untuk memfasilitasi keluarnya prolaktin dan respon oksitosin. ${ }^{10}$ Hasil penelitian menjelaskan jika ibu menggunkan teknik pemerahan menggunakan tangan akan lebih 
berpeluang memberikan ASI sebesar $96,1 \%$, sedangkan jika menggunakan alat seperti breast pump peluang memberikan ASI sebesar $72,7 \%$. Alasan ibu tetap memberikan ASI dengan pemerahan menggunakan tangan karena ibu merasa nyaman dan tidak malu saat pemerahan ASI, sehingga dapat pemerahan ASI di mana saja. ${ }^{18}$ ASI adalah "hidup" dan mengandung sel-sel dari kedua bakteri yang berasal dari ASI itu sendiri dan berasal dari luar,seperti bakteri yang berasal dari kulit ibu dan rongga mulut bayi, kehadiran bakteri dari luar tersebut dianggap sebagai indikasi adanya infeksi. ASI dapat memengaruhi memodifikasi pengembangan mikrobiota pada usus bayi ${ }^{12}$ Banyak faktor yang memengaruhi kualitas ASI dari segi jumlah bakteri, dan jamur yaitu sifat ASI itu sendiri, keadaan lingkungan, dan kondisi pengolahan atau penyimpanan. Jumlah mikroba yang terlalu tinggi dapat menubah karakter organoleptik, mengakibatkan perubahan nutrisi/nilai gizi bahkan merusak ASI tersebut. ASI merupakan salah satu jenis pangan yang diperuntukan sebagai makanan bagi manusia, kualitas ASI yang jelek dapat disebabkan oleh cemaran yang berasal dari mikroba dengan ciri-ciri bau busuk dan tengik. ${ }^{19,} 20$ Teknik pemerahan ASI mempunyai dampak terhadap kualitas ASI dari segi jumlah bakteri, teknik tersebut dapat menggunakan tangan atau manual breast pump. Berdasarkan hasil penelitian menjelaskan bahwa kontaminasi yang disebabkan oleh teknik pemerahan dapat terjadi apabila teknik pemerahan yang dilakukan tidak benar baik dari segi alat yang digunakan, atau persiapan sebelum pemerahan. Pengaruh yang ditimbulkan dapat meningkatkan jumlah bakteri, enterobakter, jamur, dan bakteri patogen yang ada pada ASI. Bakteri yang ada termasuk jenis mesofil aerob, E.coli. staphilokokkus, salmonela, pseudomonas, koliform. ${ }^{21}$ Jumlah bakteri Mesofil aerob yang ada pada ASI diperah dengan memperhatikan teknik pemerahan yang betul berkisar <105 CFU/ml, dan enterobakter $<10 \mathrm{CFU} / \mathrm{mL}$, sedangkan jika teknik pemerahan tidak betul jumlah bakteri berkisar >105 CFU/ml, dan enterobakter $\geq 10 \mathrm{~mL}$. Perbandingan secara presentase tingkat terkontaminasi oleh bakteri antara ASI yang diperah dengan teknik yang memperhatikan aseptik dengan yang tidak berkisar 59,6\% dan $39,6 \%$, sedangkan bakteri patogen tidak boleh ada pada ASI perah. hal tersebut sangat jelas bahwa pengaruh teknik pemerasan sangat signifikan terhadap jumlah bakteri pada ASI perah. ${ }^{21}$

\section{METODE}

Jenis penelitian yang digunakan dalam penelitian ini adalah Studi observasional. Dengan pendekatan Crossectional. Sampel adalah ibu menyusui. Perhitungan jumlah sampel dalam penelitian ini berdasarkan rumus perbedaan kelompok berpasangan. Teknik pengambilan sampel menggunakan acak sederhana dengan cara di undi Penelitian dilakukan dua hari, jumlah responden pada hari pertama sebanyak 17 orang dan pada hari ke dua sebanyak 18 orang. Masing-masing ibu melakukan dua jenis teknik pemerahan dalam waktu yang berbeda, setelah melakukan pemerahan, ibu mengisi kuesioner tentang kenyamanan dengan 11 item pernyataan menggunakan skala likert menghitung skor kenyamanan.

Kuesioner tersebut berisi tentang dukungan keluarga,motivasi ibu dan teknik pemerahan yang digunakan kuesioner tersebut yang diambil dari penelitian Flaherman yang sudah diuji validitas dan reliabilitas. ASI dikirim ke laboratorium Fakultas Farmasi ITB. ASI yang diperah dengan menggunakan teknik langsung dengan tangan atau breast pump sebanyak $10 \mathrm{ml}$ kemudian diuji secara laboratorium untuk mengetahui kualitas ASI dari segi bakteri, dan jamur. Alat 
yang digunakan yaitu digital colony counter dan Plat Count Agar .Subjek pada penelitian ini adalah ibu bekerja menyusui yang mempunyai bayi usia lebih dari sama dengan 14 hari di wilayah kota Bandung. jumlah sampel sebanyak 35 orang yang sudah memenuhi kriteria inklusi dan eksklusi. Pengujian statistik menggunakan analisis uji Mann Whitney, Wilcoxon, dan McNemar, dengan kemaknaan hasil uji ditentukan berdasarkan nilai $\mathrm{p}<0,05$.

\section{HASIL DAN PEMBAHASAN}

Tabel 1 Karakteristik Responden

\begin{tabular}{llcc}
\hline No & Karakteristik & Frekuensi & Persentase \\
\hline $\mathbf{1}$ & Usia & 32 & \\
& $20-35$ tahun & 3 & 81,4 \\
& $>35$ tahun & & \\
$\mathbf{2}$ & Pendidikan & 24 & 68,6 \\
& Tinggi (SMA-S1) & 11 & 31,4 \\
& Rendah (SD-SMP) & & \\
& Paritas & 25 & 71,4 \\
& 1-2 & 10 & 28,6 \\
& $>\mathbf{2}$ & & \\
& &
\end{tabular}

Berdasarkan tabel 1, diketahui bahwa pendidikan tinggi (SMA-S1) dan.Paritas sebagian besar usia ibu adalah 20-35 tahun, Pendidikan sebagian besar adalah

Tabel 2 Distribusi Frekuensi Hasil Penelitian

\begin{tabular}{|c|c|c|c|c|c|}
\hline \multirow{2}{*}{ No } & \multirow{2}{*}{$\begin{array}{c}\text { Kenyamanan dan } \\
\text { Kualitas ASI }\end{array}$} & \multicolumn{2}{|c|}{ Tangan } & \multicolumn{2}{|c|}{ Manual Breast Pump } \\
\hline & & Frekuensi & Persentase & Frekuensi & Persentase \\
\hline \multirow[t]{4}{*}{1} & Skor kenyamanan & & & & \\
\hline & $\mathrm{X}(\mathrm{SD})$ & $65,6(12,58)$ & & $59,5(14,09)$ & \\
\hline & Median & 60,0 & & 58,00 & \\
\hline & Rentang & $49-95$ & & $35-93$ & \\
\hline \multirow[t]{3}{*}{2} & Jamur & & & & \\
\hline & Aman & 14 & 40 & 7 & 20 \\
\hline & Terkontaminasi & 21 & 60 & 28 & 80 \\
\hline \multirow[t]{2}{*}{3} & Bakteri Patogen & & & & \\
\hline & Ada & 0 & 0 & 0 & 0 \\
\hline \multirow[t]{3}{*}{4} & Bakteri Enterobacter & & & & \\
\hline & $<10 \mathrm{CFU} / \mathrm{mL}$ & 29 & 82,9 & 28 & 80 \\
\hline & $\geq 10 \mathrm{CFU} / \mathrm{mL}$ & 6 & 17,1 & 7 & 20 \\
\hline \multirow[t]{3}{*}{5} & Total Bakteri & & & & \\
\hline & $<10^{5} \mathrm{CFU} / \mathrm{mL}$ & 28 & 80 & 32 & 91,4 \\
\hline & $\geq 10^{5} \mathrm{CFU} / \mathrm{mL}$ & 7 & 20 & 3 & 8,6 \\
\hline \multirow[t]{3}{*}{6} & Kualitas ASI & & & & \\
\hline & Baik & 14 & 40 & 7 & 20 \\
\hline & Buruk & 21 & 60 & 28 & 80 \\
\hline
\end{tabular}

Berdasarkan Tabel 2 didapatkan skor kenyamanan ibu lebih besar dibandingkan manual breast pump. Hasil gambaran pada ASI didapatkan bahwa jumlah jamur yang aman lebih tinggi pada ibu yang pemerahan menggunakan tangan 
bila dibandingkan dengan manual breast pump. Pada total bakteri

didapatkan bahwa ASI yang diperah

pump. Kualitas ASI pada teknik pemerahan tangan lebih baik dengan tangan memiliki keamanan lebih dibandingkan manual breast pump.

sedikit bila dibandingkan dengan yang diperah menggunakan manual breast

\section{Tabel 3 Perbedaan Teknik Pemerahan ASI Terhadap Kualitas ASI}

\begin{tabular}{|c|c|c|c|c|c|c|c|c|}
\hline \multirow{3}{*}{ No. } & \multirow{3}{*}{ Kualitas ASI } & \multicolumn{4}{|c|}{ Kualitas ASI Manual Breast Pump } & \multirow{2}{*}{ Total } & & \multirow{3}{*}{ Nilai $p$} \\
\hline & & \multirow{2}{*}{$\begin{array}{l}\text { Baik } \\
\mathbf{N}\end{array}$} & \multicolumn{3}{|c|}{ Buruk } & & \multirow[b]{2}{*}{$\%$} & \\
\hline & & & $\%$ & $\mathbf{N}$ & $\%$ & $\mathbf{N}$ & & \\
\hline & Kualitas ASI Tangan & & & & & & & \\
\hline & Baik & 5 & 35,7 & 9 & 64,3 & 14 & 100 & $0,032 *$ \\
\hline & Buruk & 2 & 9,5 & 19 & 90,5 & 21 & 100 & \\
\hline
\end{tabular}

Keterangan : Uji McNemar

pemerahan tangan lebih baik

Berdasarkan Tabel 3 Hasil uji statistik dibandingkan manual breast pump.

diperoleh Nilai $\mathrm{p}=0,032$ hal ini menunjukkan adanya perbedaan teknik pemerahan ASI terhadap kualitas ASI. Sehingga kualitas ASI pada teknik

Tabel4 Distribusi Frekuensi Pengalaman dan Sensitivitas Nyeri

\begin{tabular}{llllll}
\hline \multirow{2}{*}{ No } & Pengalaman dan & Tangan & & \multicolumn{2}{c}{ Manual Breast Pump } \\
\cline { 3 - 6 } & Sensitivitas Nyeri & Frekuensi & Persentase & Frekuensi & Persentase \\
\hline 1 & Pengalaman & & & & \\
& Berpengalaman & 15 & 42,9 & 8 & 22,9 \\
& Tidak Berpengalaman & 20 & 57,1 & 27 & 77,1 \\
2 & Sensitivitas Nyeri & & & & \\
& Tidak nyeri & 28 & 80 & 20 & 57,1 \\
& Nyeri & 7 & 20 & 15 & 42,9 \\
\hline
\end{tabular}

Berdasarkan tabel 4 didapatkan bahwa ibu yang berpengalaman melakukan pemerahan ASI sekitar 23 orang, Ibu yang merasakan tidak nyeri pemerahan dengan tangan lebih tinggi dibandingkan dengan manual breast pump.

Tabel 5 Perbedaan Pengalaman dan Sensitivitas Nyeri Terhadap Kenyamanan Ibu

\begin{tabular}{clll}
\hline Kenyamanan & \multicolumn{1}{c}{$\begin{array}{c}\text { Pengalaman } \\
(\mathbf{n = 2 3})\end{array}$} & \multicolumn{1}{c}{$\begin{array}{c}\text { Tidak Berpengalaman } \\
(\mathbf{n = 4 7 )}\end{array}$} & Nilai p \\
\hline Skor Kenyamanan & & & \\
x (SD) & $61,2(10,31)$ & $63,2(15,01)$ & $0,603 * *$ \\
Median & 58,00 & 60,00 & \\
Rentang & $49-93$ & $35-95$ & \\
\hline Variabel & \multicolumn{1}{c}{ Nyeri $(\mathbf{n = 2 2})$} & Tidak Nyeri $(\mathbf{n}=\mathbf{4 8})$ & $<0,001^{* *}$ \\
\hline Skor Kenyamanan & & & \\
X (SD) & $52,3(9,4)$ & $67,3(12,68)$ & \\
Median & 49,0 & 64,0 & \\
Rentang & $35-82$ & $36-95$ &
\end{tabular}


Hasil uji statistik diperoleh nilai $\mathrm{p}=0,603$. Hal ini menunjukkan tidak ada perbedaan kenyamanan pada teknik pemerahan tangan dengan manual breast pump. diperoleh nilai $\mathrm{p}<0,001$. Hal ini menunjukan adanya perbedaan yang signifikan skor kenyamanan pada ibu yang merasakan nyeri dibandingkan ibu yang tidak merasakan nyeri pada saat pemerahan ASI.

Tabel 6 Perbedaan Teknik Pemerahan Terhadap Kenyamanan

\begin{tabular}{llll}
\hline \multirow{2}{*}{ Kenyamanan } & \multicolumn{1}{c}{ Variabel } \\
\cline { 2 - 4 } & \multicolumn{1}{c}{$\begin{array}{c}\text { Tangan } \\
(\mathbf{n = 3 5})\end{array}$} & $\begin{array}{c}\text { Manual Breast } \\
\boldsymbol{P u m p}(\boldsymbol{n}=35)\end{array}$ & Nilai $\boldsymbol{\rho}$ \\
\hline Skor Kenyamanan & & & $0,046^{*}$ \\
X (SD) & $65,6(12,58)$ & $59,5(14,09)$ & \\
Median & 60,0 & 58,00 & \\
Rentang & $49-95$ & $35-93$ & \\
\hline
\end{tabular}

Keterangan : Uji wilcoxon*

Hasil uji statistik diperoleh $p$ value $=0,046$ hal ini menunjukkan adanya perbedaan kenyamanan ibu pada teknik pemerahan ASI tangan dibanding manual breast pump.

sehingga teknik pemerahan tangan lebih nyaman dibandingkan dengan teknik pemerahan manual breast pump.

Hasil analisis pada tabel 6 memperlihatkan mean skor kenyamanan teknik pemerahan tangan dan manual breast pump sebesar 65,6 (12,58) dan 59,5 $(14,09)$. Terdapat perbedaan teknik pemerahan terhadap kenyamanan ibu dengan nilai $\mathrm{p}<0,05$.

Hal ini sejalan dengan penelitian Flaherman yang menjelaskan bahwa teknik pemerahan yang dilakukan oleh ibu sangat dipengaruhi faktor yang mendukung yaitu: privasi dalam proses pemerahan termasuk kenyamanan dalam pemerahan, waktu, dan metode pemerahan. Penelitian tersebut menggunakan dua jenis teknik pemerahan yaitu menggunakan tangan dan Manual breast pump. $^{8}$ Teknik pemerahan menggunakan tangan meningkatkan kenyamanan dalam proses pemerahan dibandingkan menggunakan breast pump, alasan dari hasil tersebut yaitu karena ibu yang menggunakan breast pump merasa canggung dan malu pada saat pemerahan, hasil tersebut dikaji pada saat ibu ditanyakan tentang pengalaman mereka pemerahan ASI. Motivasi ibu, penyediaan peralatan pemerahan, lingkungan yang kondusif, dan keterampilan merupakan faktor penting dalam melakukan teknik pemerahan. Hasil penelitian menjelaskan ibu merasa lebih damai melakukan teknik pemerahan tangan dibandingkan menggunakan manual breast pump, Teknik pemerahan dengan tangan lebih nyaman dibandingkan teknik pemerahan menggunakan manual breast pump dengan skor skala likert > 3. Hasil penelitian menjelaskan teknik pemerahan tangan menyebabkan ibu akan tetap memberikan ASI eksklusif 96,1\% sampai 2 tahun dibandingkan teknik manual breast pump sebesar $72,7 \%$. Kenyamanan sebagai suatu keadaan telah terpenuhinya kebutuhan manusia yang bersifat individual dan holistik. Terpenuhinya kenyamanan dapat menyebabkan perasaan sejahtera pada diri individu tersebut. ${ }^{22}$ Kenyamanan yang terjadi pada ibu pada saat pemerahan ASI sangat dikaitkan dengan pengalaman ibu dalam 
pemerahan ASI, kenyamanan dalam melakukan teknik yang dilakukan sampai dukungan yang diberikan oleh orang sekitar. $^{8}$

Teknik pemerahan tangan lebih efektif dan lebih murah dibandingkan menggunakan alat. ${ }^{11}$ Pemerahan tangan merupakan bagian penting dari perawatan payudara. Teknik pemerahan tangan adalah pergerakan fisik pada payudara dengan tangan ibu, sangat mudah dilakukan, dan dapat dilakukan secara tiba-tiba dan mudah dilakukan jika bayi akan ditinggalkan bekerja. ${ }^{22}$ Manual breast pump menghasilkan daya hisap kurang dari pompa listrik dan kurang efisien dalam pengeluaran ASI. Manual breast pump mengandalkan ritme dalam pemerahan, sehingga dapat mengontrol vakum, jika mekanisme pengendalian vakum dilakukan untuk periode berkepanjangan, jaringan payudara dapat memar atau rusak. Perisai payudara dan daya hisap pada manual breast pump sangat memengaruhi kenyamanan ibu saat pemerahan. Peningkatan atau penurunan daya hisap dapat memengaruhi tingkat kenyamanan saat pemerahan.Perisai payudara yang tidak pas menyebabkan puting tidak tertarik sehingga proses pemerahan tidak berhasil. ${ }^{12}$

Hasil analisis pada tabel 6 memperlihatkan bahwa terdapat perbedaan teknik pemerahan terhadap kualitas ASI dengan Nilai $\mathrm{p}<0,05$. Kualitas ASI pada teknik pemerahan tangan lebih baik dibandingkan manual breast pump.

Sejalan dengan hasil penelitian bahwa Jumlah bakteri Mesofil aerob yang ada pada ASI diperah dengan memperhatikan teknik pemerahan yang betul berkisar $<10^{5} \mathrm{CFU} / \mathrm{mL}$, dan enterobakter $<10 \mathrm{CFU} / \mathrm{mL}$, sedangkan jika teknik pemerahan tidak betul jumlah bakteri berkisar $>10^{5} \mathrm{CFU} / \mathrm{mL}$, dan enterobakter $\geq 10 \mathrm{~mL}$. Sehingga dalam memberikan ASI harus memperhatikan kebersihan diri dan alat yang digunakan. ${ }^{23}$ Perbandingan secara presentase tingkat terkontaminasi oleh bakteri antara ASI yang diperah dengan teknik yang memperhatikan aseptik dengan yang tidak berkisar $59,6 \%$ dan $39,6 \%$, sedangkan bakteri patogen tidak boleh ada pada ASI perah. Hal tersebut sangat jelas bahwa pengaruh teknik pemerasan sangat signifikan terhadap jumlah bakteri pada ASI perah. Pada penelitian ini teknik pemerahan tangan mempunyai kontaminasi jamur sebanyak $60 \%$, jumlah enterobakter $17,1 \%$, dan jumalh bakteri mesofil $20 \%$, sedangkan kualitas ASI dengan teknik pemerahan manual breast pump terkontaminasi jamur sebanyak $80 \%$, jumlah enterobakter $20 \%$, dan jumlah bakteri mesofil $8,6 \%{ }^{24}$

Hasil tersebut sejalan dengan penelitian lain menjelaskan ASI yang diperah di rumah menggunakan breast pump mempunyai resiko $86,3 \%$ terkontaminasi dibandingkan ASI yang diperah menggunakan tangan langsung sebesar $61,0 \%$, sedangkan jika pemerahan dilakukan di rumah sakit yang kesterilannya dijaga maka tidak ada perbedaan antara yang diperah menggunakan tangan atau breast pump. Jumlah bakteri Mesofil aerob sebesar $39,2 \%$, jumlah enterobakter $9,4 \%$, bakteri staphylokokkus $7,9 \%$, dan E.coli $4.3 \% .^{25}$

Sejalan dengan penelitian lain menjelaskan bahwa kontaminasi jamur pada ASI sebanyak 5,7\% dengan rata-rata total jumlah jamur $>10^{3} \mathrm{CFU} / \mathrm{mL}$. Hal tersebut dikarenakan bahwa pemeran utama terjadinya kontaminasi jamur adalah proses hygiene yang tidak baik seperti cuci tangan dan persiapan alat, sehingga mengakibatkan ASI yang diperah terkontaminasi jamur yang berbahaya seperti jenis micelial. ${ }^{26}$ Jumlah total bakteri dalam ASI mempunyai jumlah sekitar kurang dari 100.000 $\mathrm{CFU} / \mathrm{mL}$. Sebuah penelitian memperkirakan bahwa bayi yang 
mengkonsumsi ASI sekitar $800 \mathrm{~mL}$ bayi / per hari mungkin menelan sekitar $10^{5}$ $10^{7}$ bakteri.Kehadiran bakteri dan jamur dalam ASI tersebut sangat dipengaruhi oleh persiapan sebelum pemerahan ASI, persiapan tersebut meliputi persiapan ibu (mencuci tangan, membersihkan bagian payudara, dll), persiapan alat pompa (mencuci alat, mensterilkan alat), dan lingkungan. Jika persiapan tidak maksimal maka akan terjadi kontaminasi silang sehingga bakteri dan jamur akan menempel pada ibu dan alat kemudian masuk melalui lubang puting, aerola dan masuk ke duktus atau saluran payudara, sehingga akan mencemari ASI pada saat diperah. $^{28}$ Teknik pemerahan tangan meminimalkan terjadinya kontaminasi bakteri pada ASI dibandingkan pemerahan menggunakan manual breast pump. ${ }^{28}$

Kehadiran jamur dalam ASI berhubungan langsung dengan kebiasaan atau budaya, efisien cuci tangan menunjukkan jamur pada ASI. Mencuci tangan sebelum pemerahan sangat penting untuk mengurangi jumlah spora jamur yang menempel pada ASI. ${ }^{27}$

Prevalensi 69,4\% dari jamur dan ragi dalam sampel diperoleh setelah menggunakan metode kebersihan biasa (sabun dan air). Peneliti lain, mengamati bahwa $230(6,5 \%)$ dari total 7.570 sampel yang dianalisis terdapat cetakan jamur dan ragi. ${ }^{17}$ Jumlah kontaminasi bakteri dari ASI yang diperoleh dengan manual breast pump lebih tinggi dibandingkan pemerahan dengan tangan, upaya yang harus dilakukan oleh ibu adalah untuk memerhatikan prosedur desinfektan.

Pemerahan ASI yang dilakukan jauh dari fasilitas kesehatan, tetapi melakukan pemerahan sesuai prosedur, mungkin akan sedikit terkontaminasi oleh bakteri maupun jamur. ${ }^{28}$

\section{KESIMPULAN}

Kesimpulan dari penelitian ini yaitu: teknik pemerahan tangan lebih nyaman dan mempunyai kualitas ASI lebih baik dibandingkan teknik pemerahan Manual breast pump.

\section{DAFTAR PUSTAKA}

1. WHO. Global strategy on infant and young child feeding. Executive Board Paper. Geneva: WHO. 2002.

2. Peraturan Pemerintah Republik Indonesia Nomor 33. Pemberian air susu ibu eksklusif. 2012.

3. Profil Kesehatan Kota Bandung. 2013.

4. Alina $\mathrm{T}$, Ismail $\mathrm{T}$, Sulaiman $\mathrm{Z}$, Jalil R, Muda WM, Man NN. Breast milk expression among formally employed women in urban and rural Malaysia: A qualitative study. Int Breastfeed J. 2012;7(11):1-8.

5. Rejeki S. Studi fenomenologi: Pengalaman menyusui eksklusif ibu bekerja di wilayah kendal jawa tengah. Media Ners. 2008

6. Pusat Data Informasi Kementerian Kesehatan RI. Mari mendukung! menyusui dan bekerja 1-7 Agustus “ pekan ASI sedunia. 2015.

7. Asosiasi Ibu Menyusui Indonesia. Pedoman lingkungan ramah laktasi. Jakarta. 2012.

8. Flaherman VJ, Gay B, Scott C, Aby J, Stewart AL, Lee KA. Development of the breast milk expression experience measure. Matern Child Nutr. 2013;9(3):425-30.

9. Mc Clellan HL, Hepworth AR, Garbin CP, Rowan MK, Deacon J, Hartmann PE, Geddes DT. Nipple pain during breastfeeding with or without visible trauma. J Hum Lact. 2012;28(4):511-21.

10. Flaherman VJ, Gay B, Scott C, Avins A, Lee KA, Newman TB. Randomized trial comparing hand expression with breast pumping for mothers of term newborns feeding poorly. Arch Dis Child Fetal Neonatal Ed. 2011:1-6. 
11. Jones E, Dimmock PW, Spencer SA. A randomized controlled trial to compare methods of milk expression after preterm delivery. Arch Dis Child Fetal Neonatal. 2015;85:91-5.

12. Bode L, McGuire M, Rodriguez JM, Geddes DT, Hassotou F, McGuire MK. It's Alive: microbes and cells in human milk and their potential benefits to mother and infant. Am Soc Nutr. 2014;5:571-3

13. Setegn T, Belachew T, Gerbaba M, Deribe K, Deribew A, Biadgilign. Factors associated with exclusive breastfeeding practices among mothers in Goba district, south east Ethiopia: a cross-sectional study. Int Breastfeed J. 2012;7(17):1-8.

14. Hakim L. Perkembangan tenaga kerja wanita di sektor informal: hasil analisa dan proxy data sensus penduduk. 2011.

15. Afrose L, Banu B, Ahmed KR, Khanom K. Factors associated with knowledge about breastfeeding among female garment workers in Dhaka city. South-East Asia J Public Health. 2012;1(3):249-55

16. Alina T, Ismail T, Sulaiman Z, Jalil R, Muda WM, Man NN. Breast milk expression among formally employed women in urban and rural Malaysia: A qualitative study. Int Breastfeed J. 2012;7(11):1-8

17. Protocol A. ABM clinical protocol\# 8: human milk storage information for home use for full-term infants (original protocol March 2004; revision\# 1 March 2010). Breastfeed Med. 2010;5(3).

18. Badan POM RI. Pengujian mikrobiologi pangan. 2008:1-5.

19. Serra VV, Teves S, Lopez A, Ossorio F, Aguilar N, Arm M. Comparison of the risk of microbiological contamination between samples of breast milk obtained at home and at a healthcare facility. Arch Argent Pediatr. 2013;111(2):115-9.

20. Keating EM, Curtis BA, Slusher TM. Maternal milk volume and breast milk expression: implications for diet and nutrition in infant. 2013.

21. Kolcaba K, Tilton C, Drovin C. Comfort teory: A unifying framework to enhance the practice environment. J Nurs Adm. 2006;36:538-44.

22. Badan POM RI. Pengujian mikrobiologi pangan. 2008:1-5.

23. Serra VV, Teves S, Lopez A, Ossorio F, Aguilar N, Arm M. Comparison of the risk of microbiological contamination between samples of breast milk obtained at home and at a healthcare facility. Arch Argent Pediatr. 2013;111(2):115-9.

24. Franz R. Novak,João A, Manoel J.S, Bodo W. Contamination of expressed human milk by mycelial fungi. J Pediatr. 2002;78(3):197-201.

25. Yin Sd. Bacteria, viruses, membraneenclosed microentities, and fungi as the environmental evolutionary entities coexisting in human milk. $\mathbf{J}$ Theor Fimpology. 2014;2(2):1-11.

26. The Academy of Breastfeeding Medicine Protocol Committee. ABM clinical protocol \#8: human milk storage information for home use for full-term infants (Original Protocol March 2004; revision \#1 march 2010). breastfeed Med. 2010;5(3):127-30.

27. Bharadva K, Tiwari S, Mishra S, Mukhopadhyay K, Yadav B, Agarwal R. Human milk banking guidelines. Indian Pediatr.2014;51:469-74.

28. WHO. Breastfeeding counseling. Sessions 20-30. UNICEF. 